\title{
Erratum to: Altering conditions for student participation and motive development in school science: learning from Helena's mistake
}

\section{Maria Andrée}

Published online: 17 January 2012

(C) Springer Science+Business Media B.V. 2012

\section{Erratum to: Cult Stud of Sci Educ \\ DOI 10.1007/s11422-011-9314-x}

Due to a typing error, the task description in the case accounted for was mixed up in the third paragraph of the section "The mistaken acid". The task description should read:

In the first task, the students are instructed to dissolve cupper oxide in sulphuric acid. In the second task, the students are instructed to dissolve zinc in hydrochloric acid. It should be noted that the cupper oxide referred to is cupper (II) oxide, or cupric oxide, $(\mathrm{CuO})$.

The online version of the original article can be found under doi:10.1007/s11422-011-9314-x.

M. Andrée $(\bowtie)$

Department of Mathematics and Science Education, Stockholm University, Stockholm, Sweden e-mail: maria.andree@mnd.su.se 